\title{
Educators' interpretations of children's belonging across borders: Thinking and talking with an image
}

\begin{abstract}
:
The European quality framework for early childhood education and care (European Commission, 2020) calls for creating environments that support all children's sense of belonging. This study aims to advance empirical knowledge on educators' interpretations of children's belonging in early education settings. The study is part of a project conducted in five European countries-Finland, Iceland, the Netherlands, Norway and Sweden. The following research question guides the study: How do educators interpret children's belonging in early education across borders? The study draws from the theory of the politics of belonging (Yuval-Davis, 2011) and employs 'thinking and talking with an image' as a methodological approach. The findings explicate educators' taken-for-granted categorisations, thus portraying their views about educational settings as sites for children's belonging. Opposing, joint play and being alone were identified as emotionally loaded interactions that educators interpreted as significant for children's belonging. The educators emphasised democratic values, such as diversity, participation, equality and equity. However, they viewed diverse tensions in embodying democratic values in a diverse group. The shared basis of the profession appeared as a more significant basis for educators' interpretations than the different societal contexts. The study encourages educators and researchers in European countries to collaborate in promoting children's belonging.
\end{abstract}

Keywords: Belonging, children, cross-cultural, early childhood education, educator, interpretation, visual methodologies

\section{Introduction}

This study focuses on educators' interpretations on children's belonging in early education settings. Scholars largely agree that belonging is a fundamental human need that influences children's learning, social behaviour, well-being and identity (May, 2013; Over, 2016; Stratigos et al., 2014). There is also a wide consensus that from early years onward, education has a key role in promoting common European values and principles that are closely connected to belonging, such as human dignity, equality and inclusion (Council of the European Union, 2018; also Ainscow, 2020; Urban, 2015). The European quality framework for early childhood education and care states that "creating a welcoming environment for children that values their languages, culture and home backgrounds contributes to the development of their sense of belonging" (European Commission, 2020: 145).

However, it has become increasingly challenging for educators to promote all children's belonging in educational settings. Over the past decades, European countries have confronted new social realities characterised by increasing diversity, mobility and pluralism, that challenge the traditional monocultural bases of education (García-Sánchez and Nazimova, 2017). There is a growing concern about children's marginalisation, as there is evidence that even young children encounter exclusion, rejection, withdrawal and bullying in educational settings (Juutinen, 2018; Skoglund, 
2020; Urban, 2015). Promoting children's belonging in a diverse and mobile world is addressed as a crucial challenge for education in the $21^{\text {st }}$ century (Healy and Richardson, 2017).

This study is part of a larger project in which researchers from five European countries-Finland, Iceland, the Netherlands, Norway and Sweden-collaborate with the aim of advancing knowledge about young children's belonging in educational settings. The project approaches children's belonging as a multi-level phenomenon that is shaped by both macro-level policies and micro-level interactions and relations. This sub-study addresses educators' interpretations of how children's belonging is shaped at the micro-level of educational institutions. Thus, the purpose of this study is not to reveal national-level similarities or differences but, rather, to advance knowledge about educational institutions as sites for children's belonging. Drawing on the micro-political perspective, we assume that educational institutions do not operate in a neutral way but, rather, have powerful functions in supporting or restricting children's belonging (Karlsson, 2019; Kelchtermans and Vanassche, 2017). On one hand, educational institutions provide unique opportunities for promoting children's belonging by offering shared everyday contexts for children of different backgrounds (Nutbrown and Clough, 2009). On the other, educational institutions may strengthen children's sociocultural differences and exclusion, if institutional practices and cultures are not favourable to children's belonging (Terhart and von Dewitz, 2018; Urban, 2015).

Children's belonging stems from educators who support children's positive attitudes towards diversity (Nutbrown and Clough, 2009). Even though the crucial roles of educators in children's belonging is recognised, few studies have explicitly addressed educators' views of children's belonging (Tillett and Wong, 2018). This study aims to advance empirical knowledge of this matter in the countries involved in the project. Even if the aim is not to compare the educators' interpretations, there is an openness to finding similarities and differences within and among the countries. The following research question guides the study: How do educators interpret children's belonging in early education settings across borders? In accordance with international definitions, early education in this study refers to education of children aged between one and eight years (Couchenour and Chrisman, 2016). However, most of the participating educators worked with children aged under seven years.

\section{The politics of belonging as a theoretical approach}

The present study applies Yuval Davis's (2011) theory of the politics of belonging. This perspective highlights belonging as complex processes and structures through which belonging is produced. Yuval-Davis (2006: 204) portrays the politics of belonging in terms of boundary maintenance; "the politics of belonging is all about potentially meeting other people and deciding whether they stand inside or outside the imaginary boundary line of the nation and/or other communities of belonging, whether they are 'us' or 'them." Importantly, Yuval-Davis (2010) remarks that, as boundarymaintenance, the politics of belonging concerns both inclusion and exclusion.

Applying this idea means directing attention towards the collective rather than the individual, based on the idea that different collectives or groups produce the boundaries for belonging (Nagel, 2011). In this study, early education settings are viewed as arenas where power is intertwined with and produced in different relationships: intergenerational relationships between children and adults, relationships between different professional groups and relationships between professionals and parents. Moreover, power is embedded in the pedagogical and institutional practices that shape the social spaces of normality and frame children's belonging (Puroila and Estola, 2014). Thus, the politics of belonging highlight the ethical and political values, ideologies and power relations through 
which boundaries between individuals and groups of people are produced (Yuval-Davis, 2011; also Juutinen, 2018; Rosenberger and Stöckl, 2016; Sumsion and Wong, 2011).

As Yuval-Davis (2011) notes, people cannot simply be defined as either belonging or not belonging; therefore, many analytical lenses are needed to explore how the boundaries of belonging are shaped within a collectivity. To interpret and understand belonging, she developed an analytical framework including three interrelated dimensions. The first dimension concerns an individual's belonging to particular categories, such as sex, age group, ethnic group, social class or nation. Yuval-Davis (2006) calls such categories social locations. She states that individuals' social locations are usually constructed along multiple and mutually constitutive dimensions of differences. Moreover, YuvalDavis (2011) argues that being located in certain groups is crucial for belonging, as it has implications for power relations in society. The second dimension refers to human identifications and emotional attachments to these categories or groupings; that is, one's own or others' perceptions of what being a member of certain groups might mean. The third dimension concerns ethical and political value systems. Values are central for belonging; belonging is not only about social locations, identifications and emotional attachments, but also how these are assessed and valued by the self and others (YuvalDavis, 2011). Moreover, Yuval-Davis (2011: 18) notes that contestations, tensions and value conflicts are where one moves "from the realm of belonging to that of the politics of belonging." These three dimensions are used in analysing and interpreting our research material.

\section{Previous research}

Previous studies on young children's belonging have emphasised its social nature, that is, togetherness between children and other people (Hännikäinen, 2007; Over, 2016). Hännikäinen (2007) connects togetherness with children's positive social relations; a feeling that children create together with other people through shared activities. Over (2016) maintains that children's sense of belonging requires positive, stable and enduring relations. Another theme emerging from the research is children's connectedness to places (Healy and Richardson, 2017; Kyrönlampi et al., 2021; Wastell and Degotardi, 2017). Kyrönlampi et al. (2021) highlight the importance of educational settings in shaping children's place-belonging. Their study shows how children actively make meanings from their surroundings and how adults both facilitate and impede places for children's play. The findings concerning children's place-belonging challenge to broaden the examination of belonging from social relationships to the nexus of different relationships between individuals and their environments. The studies reveal, for instance, the significance of the material environment and cultural practices, such as architecture, fences, furniture, colours, rules and routines, for children's belonging in educational settings (Juutinen, 2018; Sumsion and Wong, 2011).

Research literature portrays challenges in the implementation of inclusive education; for example, educators' lack of requisite knowledge and skills, and challenges with resources, curricula and policies (Piškur et al., 2017; Zabeli \& Glejaj, 2020). It is argued that educators' support for the participation of diverse children is typically high in rhetoric and low in practical application (Phillips, 2010). Moreover, there are studies criticising the limited understanding of inclusion as gathering children with different needs together in the same place (Stratigos et al., 2014). These studies call for going beyond the view of inclusion as physical presence, toward a view of how belonging is shaped in relations between children and their environments in educational settings.

Juutinen et al. (2018) took a relational approach when investigating belonging and exclusion processes in early education. They found different tensions involved in the processes of belonging, like tensions between stability and variability; including and excluding; and individuality and collectivity. Belonging, as a relational phenomenon, is also studied by several researchers in terms of 
togetherness and participation. Ree and Emilson (2019) show how co-operative communication contributes to mutual participation and children's belonging in a community, whereas controlling and supportive communication become restricting. Sharing life-worlds and being included in collective activities is, according to Johansson (2017), fundamental for children's sense of belonging in their everyday lives in educational settings. Children's sense of belonging in a community also evolves gradually through experiences in joint play, stable friendships and emotional bonding (Koivula and Hännikäinen, 2016).

Despite the growing interest in preventing children's exclusion and enhancing their belonging, we know little about how belonging is shaped in children's daily lives in early education settings (Johansson, 2017). Research on educators' understandings of children's belonging is scant (Tillett and Wong, 2018). This study aims to advance empirical knowledge of these matters in different educational settings involved in the project.

\section{Combining visual and interpretive approaches}

This study combines visual and interpretive approaches in exploring educators' interpretations of children's belonging in a cross-cultural research context. The study is methodologically inspired by recent discussions of interpretive approaches in cross-cultural research. Cross-cultural studies predominantly rest on quantitative methodologies that employ large-scale research material and direct comparisons between participating countries (McNess et al., 2015; Puroila and Johansson, 2018). Although these methodologies are appropriate for exploring large numbers of cases, quantitative comparative studies often fail to capture context-specific and deep insider knowledge (Wendt, 2020). Recent studies call for problematising the borders that are crossed in cross-cultural studies; it is highlighted that people's identities can be flexible and the boundaries between who is inside or outside a nation are nowadays less easy to draw (McNess et al., 2015; Milligan, 2016). Therefore, there is a growing interest in developing interpretive methodologies in which the essentialist assumptions about national borders, researchers' and participants' positions and knowledge production are problematised (Milligan, 2016; Puroila and Johansson, 2018; Wendt, 2020).

From the first steps of this study, we were aware of these methodological challenges in crosscultural research. We acknowledged how tightly cultures, languages and meanings are intertwined, and how meanings can be lost in translation (Puroila and Johansson, 2018). As our interest was in educators' interpretations of children's belonging in a cross-cultural context, we needed methodological tools that enabled us to co-create knowledge across national and linguistic borders while remaining sensitive to context-specific and nuanced interpretations. We developed a research design in which an external illustrator drew an image about an everyday life situation in an educational setting, to be discussed by educators and researchers across the participating countries. Bleiker (2015) remarks that images operate at many overlapping levels; they involve potential to work across national borders and between the physical and mental worlds. There are studies suggesting that visual material, such as photos, drawings, and images, can supplement verballybased methods in human research (Boden et al., 2019). However, it is worth acknowledging that images, like other methods, are selective and have a vantage point that both reveals and conceals (Bleiker, 2015).

This study draws on the idea that looking, seeing, talking and knowing form intertwining elements of social life (Allan and Tinkler 2015; Rose, 2016). In accordance with Traue et al., (2019), we assume that an image is not just a representation of the social world, but involves cultural meanings, social practices and power relations. As Rose (2016) reminds, images are never innocent nor neutral but, rather, are embedded in the social world. She suggests four significant criteria for the interpretation 
of images: 1) how images are produced; 2) the composition of images; 3 ) the circulation of images; and 4) how various audiences view images. Even though all these criteria are important for the methodology of the present study, the last - the way the image is viewed - is at the forefront. We call this approach thinking and talking with the image.

Thinking and talking with the image involved interpretations at several levels that demonstrate the thoroughly interpretive nature of this study. First, the image, as such, was not a neutral expression about early education settings; rather, the illustrator inserted her own interpretations into the image. Second, the educators interpreted the image in the light of their cultural understandings. Third, we researchers collaborated to interpret the educators' discussions. This is how knowledge was constructed as a multi-level process of interpretation. Rather than generating direct comparisons between the countries, the image created opportunities for meaning-making between itself and the illustrator, the educators and the researchers. The study's highly interpretive nature is both its strength and its limitation; it offers insights into educators' cultural knowledge in a cross-cultural context, but does not allow generalisation of the findings beyond the research context. Rather, the study invites readers to evaluate how its findings resonate with their own cultural knowledge.

\section{The study}

\section{Context of the study: Young children's education in five European countries}

Five European countries-Finland, Iceland, the Netherlands, Norway and Sweden- provided various contexts for the study, as their early education and care systems differ. A recent European report on educational systems shows that there are differences between countries in the government, access and integration of educational services for young children (Eurydice, 2019; also OECD, 2017). In the Nordic countries (Finland, Iceland, Norway, and Sweden), childcare and early education are integrated, whereas in the Netherlands, there are separate childcare services for children aged under four years and educational services for children aged four and older. There are also differences regarding the ages at which children attend primary school. In Finland and Sweden, primary school begins at age of seven, but there is a pre-primary school phase before that. In Norway and Iceland, primary school begins at age six. In the Netherlands, primary school begins at age six, but education is compulsory from the age of five; pre-primary education for four- and fiveyears-olds is provided in schools. (Eurydice, 2019; OECD, 2017.)

The countries exhibit variations in their requirements for staff qualifications in early education. However, early education is usually conducted as teamwork; team members represent different professional groups, such as teachers, nurses and assistants. Typically, teachers are required to have the highest qualifications of the team members. In Iceland, they are required to have a master's degree. In Finland, Sweden and Norway, they must have a bachelor's degree. In the Netherlands, staff qualifications differ between settings for younger and older children. (Eurydice, 2019; OECD, 2017.)

Regardless of the different national contexts and educational systems, the principles of children's participation, inclusion and belonging are embedded in educational policies in all participating countries. In the past few decades, there have been major international efforts to provide educational environments that are welcoming for all children regardless their ethnic and linguistic backgrounds or individual needs (Ainscow, 2020). Guo and Dalli (2016) note that ensuring children's sense of belonging has become a worldwide curricular goal in early education. 


\section{Producing the image for the study}

An illustrator was invited to provide an image for use by the study. As the first author is from Finland, a Finnish arts and education student was asked to collaborate with the research team for practical reasons. The Finnish research team informed the illustrator about the study and about how the image was to be used. Moreover, the researchers and the illustrator discussed previous research on children's belonging in educational settings. For instance, multiple sources of children's belonging were addressed, such as social relations, interactions, physical and material environment and educational practices (Juutinen, 2018; Sumsion and Wong, 2011). The illustrator's task was to provide an image about an everyday life situation in an early education setting. It was highlighted that the image should be thought-provoking and contain different cues to the politics of belonging, including power, confrontation, tensions, positions and ethical and political values.

The first version of the image was discussed by the international research team. Researchers reflected on how relevant the image was from the perspective of their different contexts and commented on how to elaborate on it. The illustrator was asked to insert more diversity in the image, without falling into stereotypes. For instance, it was noted that there should be various cues to diverse children's needs rather than one child in a wheelchair. The artist then composed an elaborated version of the image. The international research team agreed to use this version in all countries (APPENDIX 1).

\section{Participants, early education settings, and researchers}

Each national research team recruited collaborative educational settings for the entire project. Participation was voluntary and the participants were able to withdraw at any point of the project. When planning the present sub-study, we agreed to use educators' group discussions around the image from 10 educational settings, two settings from each country. The selection criterion was that the image had inspired lively discussion among educators in these settings. As is the case in highquality interpretive studies, we attempted to produce rich and multi-vocal research material in which children's belonging is approached from multiple angles (see Tracy, 2010).

Altogether, 38 educators from 10 early education settings participated in the study, serving as audiences for the image. In Finland, Norway, Sweden and Iceland, the educators worked with children under the school age, while in the Netherlands the educators worked in a primary school context with four- to five-years-old children. In interpretative studies, the participants' and researchers' backgrounds are noteworthy, as their capacities for interpreting the social world are framed by their prior experiences (Anderson-Levitt, 2012). As Table 1 shows, most educators were female and worked with children aged between one and seven years representing diverse linguistic and ethnic backgrounds. There were also children with special needs in the groups. Hence, it is likely that the participants had encountered issues concerning inclusion and belonging in their daily work. With a few exceptions, the educators themselves represented the major linguistic and national backgrounds of their countries.

The study was implemented by an international, multidisciplinary research team consisting of five researchers, one from each country. Before the project, we had explored phenomena around children's belonging in different disciplines: early childhood education, social sciences and occupational therapy. Combining different national and linguistic backgrounds enabled working both at national and international levels in the research process. On one hand, each researcher was able to communicate with the educators from their country with the educators' own language, which helped 
to understand nuanced meanings. On the other hand, the international team provided opportunities for researchers from different contexts to look at the research material together, thus enriching the analysis and interpretation process.

Table 1. Participants ${ }^{1}$, researchers and settings

\begin{tabular}{|c|c|c|c|}
\hline Countries & Settings & $\begin{array}{l}\text { Educators and researchers } \\
\text { (gender and nationality) }\end{array}$ & Group of children \\
\hline \multirow[t]{2}{*}{ Finland } & 1 & $\begin{array}{l}-2 \text { educators }(\mathrm{F}, \text { Finnish }) \\
-1 \text { educator }(\mathrm{M}, \text { Finnish }) \\
-1 \text { researcher }(\mathrm{F}, \text { Finnish }) \\
-1 \text { research assistant }(\mathrm{F}, \text { Finnish })\end{array}$ & $\begin{array}{l}\text {-The educators worked in a same group of children, aged } \\
6-7 \text { years. } \\
-11 \text { children with minority linguistic and cultural } \\
\text { backgrounds , } 9 \text { different languages } \\
-1 \text { child with special needs }\end{array}$ \\
\hline & 2 & $\begin{array}{l}-4 \text { educators }(\mathrm{F}, \text { Finnish }) \\
-1 \text { esearcher }(\mathrm{F}, \text { Finnish })\end{array}$ & $\begin{array}{l}\text {-The educators worked in a same group with children, } \\
\text { aged } 3 \text {-4years } \\
-8 \text { children with minor linguistic and cultural } \\
\text { backgrounds } \\
\text {-Children with special needs }\end{array}$ \\
\hline \multirow[t]{2}{*}{ Iceland } & 1 & $\begin{array}{l}-2 \text { educators }(\mathrm{F}, \text { Icelandic }) \\
-1 \text { educator }(\mathrm{F}, \\
\text { Spanish/American }) \\
-1 \text { researcher }(\mathrm{F}, \text { Icelandic })\end{array}$ & $\begin{array}{l}\text {-The educators worked in a same group with children, } \\
\text { aged } 3-5 \text { years } \\
-11 \text { children with minority linguistic and cultural } \\
\text { backgrounds } \\
\text {-Children with special needs }\end{array}$ \\
\hline & 2 & $\begin{array}{l}-1 \text { educator, }(\mathrm{M}, \text { Danish }) \\
-2 \text { educators }(\mathrm{F}, \text { Icelandic }) \\
-1 \text { researcher }(\mathrm{F}, \text { Icelandic })\end{array}$ & $\begin{array}{l}\text {-The educators worked in a same group with children, } \\
\text { aged } 5-6 \text { years } \\
-13 \text { children with minority linguistic and cultural } \\
\text { backgrounds }\end{array}$ \\
\hline \multirow[t]{2}{*}{$\begin{array}{l}\text { The } \\
\text { Nether- } \\
\text { lands }\end{array}$} & 1 & $\begin{array}{l}-3 \text { educators }(\mathrm{F}, \text { Dutch }) \\
-1 \text { research assistant }(\mathrm{F}, \text { Dutch }) \\
-1 \text { researcher }(\mathrm{F}, \text { Slovenian })\end{array}$ & $\begin{array}{l}\text {-The educators worked in separate groups of children } \\
\text { aged between } 4-5 \text { years } \\
-5 \text { children with minor linguistic and cultural } \\
\text { backgrounds } \\
-2 \text { children with special needs }\end{array}$ \\
\hline & 2 & $\begin{array}{l}-3 \text { educators }(\mathrm{F}, \text { Dutch }) \\
-1 \text { research assistant }(\mathrm{F}, \text { Dutch }) \\
-1 \text { researcher }(\mathrm{F}, \text { German })\end{array}$ & $\begin{array}{l}\text {-The educators worked in separate groups of children } \\
\text { aged between } 4-5 \text { years } \\
-6 \text { children with minor linguistic and cultural } \\
\text { backgrounds } \\
-1 \text { child with special needs } \\
\end{array}$ \\
\hline \multirow[t]{2}{*}{ Norway } & 1 & $\begin{array}{l}-3 \text { educators }(\mathrm{F}, \text { Norwegian }) \\
-1 \text { educator }(\mathrm{F}, \text { Danish) } \\
-1 \text { researcher }(\mathrm{F}, \text { Norwegian }) \\
\end{array}$ & $\begin{array}{l}\text {-The educators worked in a same group of children aged } \\
4 \text { years } \\
-4 \text { children with none-Scandinavian mother language } \\
\end{array}$ \\
\hline & 2 & $\begin{array}{l}-3 \text { educators }(\mathrm{F}, \text { Norwegian }) \\
-1 \text { educator }(\mathrm{M}, \text { Norwegian }) \\
-1 \text { researcher }(\mathrm{M}, \text { Norwegian }) \\
\end{array}$ & $\begin{array}{l}\text {-The educators worked in a same group of children, aged } \\
3 \text { years } \\
-4 \text { children with none-Scandinavian mother language }\end{array}$ \\
\hline \multirow[t]{2}{*}{ Sweden } & 1 & $\begin{array}{l}-4 \text { educators }(\mathrm{F}, \text { Swedish }) \\
-1 \text { researcher }(\mathrm{F}, \text { Swedish })\end{array}$ & $\begin{array}{l}\text {-The educators worked in a same group of children, aged } \\
1-5 \text { years } \\
\text {-Some children with different linguistic and cultural } \\
\text { backgrounds (Swedish and Arabic) }\end{array}$ \\
\hline & 2 & $\begin{array}{l}-6 \text { educators }(\mathrm{F}, \text { Swedish }) \\
-1 \text { educator }(\mathrm{F}, \text { Syria }) \\
-1 \text { researcher }(\mathrm{F}, \text { Swedish })\end{array}$ & $\begin{array}{l}\text {-The educators worked in a same group of children, aged } \\
4-5 \text { years } \\
\text {-Some children with special needs, and different linguistic } \\
\text { and cultural backgrounds; } 98 \% \text { of the children in the } \\
\text { whole preschool had another mother tongue than } \\
\text { Swedish. }\end{array}$ \\
\hline
\end{tabular}

\footnotetext{
${ }^{1}$ In this study, the term 'an educator' refers to all professional groups of educators who work with children in early education settings in different countries (teachers, nurses, special education teachers, social pedagogues, assistants).
} 


\section{Generating research material}

The research material was generated through group discussions among educators using a semistructured interview guide. The image was employed to inspire educators to think and talk with the image. In the beginning of the group discussions, the educators were asked to look at the image and freely narrate what they saw in it. After that, themes from the interview guide were discussed. The themes for the group discussions were drawn from previous research on belonging (e.g. Juutinen, 2018; Sumsion and Wong, 2011); the purpose was to address children's belonging from multiple angles, such as individual children, social relationships, material environment, pedagogical practices, power relations, tensions, dilemmas and conflicts. However, we did not restrict the discussions to issues that were directly connected to these themes. We attempted to create an informal atmosphere wherein the educators were able to freely reflect on their views and share ideas about children's belonging. The researchers' role was to inspire and challenge educators' discussions, ask clarifying questions and ask educators to exemplify the issues they were addressing. During the discussions, the educators often referred to the image and compared their own practices with what they saw in it. Each group discussion lasted around one hour. The discussions were recorded and transcribed. Altogether, the material consists of 285 pages of written text (Table 2).

Table 2. Research material

\begin{tabular}{|l|l|l|}
\hline Countries & Settings & $\begin{array}{l}\text { Research material } \\
\text { (Times New Roman, font size 12) }\end{array}$ \\
\hline Finland & Setting 1 & 54 pages \\
\cline { 2 - 3 } & Setting 2 & 31 pages \\
\hline Iceland & Setting 1 & 25 pages \\
\cline { 2 - 3 } & Setting 2 & 22 pages \\
\hline The Netherlands & Setting 1 & 24 pages \\
\cline { 2 - 3 } & Setting 2 & 33 pages \\
\hline Norway & Setting 1 & 27 pages \\
\cline { 2 - 3 } & Setting 2 & 21 pages \\
\hline Sweden & Setting 1 & 24 pages \\
\cline { 2 - 3 } & Setting 2 & 24 pages \\
\hline
\end{tabular}

\section{Analysis}

The analysis proceeded through several phases and included interpreting the research material at national and international levels. First, we read the material produced in our own countries to familiarise ourselves with the contents and identify those parts of the discussions that are connected to the image. During the second phase, we conducted an inductive, data-driven analysis in each country with the parts of the group discussions that were connected with the image. The analysis focused on the contents of the discussions; that is, what the educators talked about, and how they talked about it, when looking at the image. When discussing preliminary notions from the nationlevel analyses in the international research team, we found that educators in all countries drew attention to the following themes regarding the image: people, physical and social environment, practices, emotions and interactions. Additionally, educators in all countries reflected on what they found familiar or strange in the image compared to their own contexts. 
While the first and second phase occurred at the national level, the third phase proceeded at the international level. The researchers in each country identified excerpts from the research material regarding the aforementioned themes and translated them into English. This enabled us to read and interpret the material across national and linguistic borders. During this phase, the international research team worked together to analyse the translated excerpts in light of Yuval-Davis's (2011) three dimensions of belonging: social locations; identifications and emotional attachments; and ethical and political values. This framework helped us to analyse the educators' interpretations from various angles: how educators categorised people in the image into different social locations; how they developed emotionally loaded narratives about who the people in the image were; and how they valued and judged the matters they saw in the image.

\section{Findings}

The educators' group discussions around the image provided a rich ground for exploring their views of children's belonging. The material offered insights into the micro-political context of institutional early education within which children's belonging is shaped, promoted and restricted. Below, we introduce our findings in three sections.

\section{Children's belonging: Categorising people in educational settings}

Categorising people emerged as a significant part of educators' interpretations of the image. It was interesting how similarly educators produced the categories in their talk regardless of their national backgrounds, and how widely they took these categories for granted. The categorising seemed to be an un-reflective process in which the educators read cues embedded in the image and differentiated people within it, thus shaping these people's belonging to particular social locations.

As revealed by the excerpts below, the educators categorised people in the image according to their gender (girl, boy, woman, man, mother) and generation (child, adult). The adults were further divided into the categories of professionals (teachers) and parents (mother). Identifying someone as a teacher shows how the educators connected the image to the institutional context of education. These categories thus illustrate the educators' understanding of the social milieu within which children's belonging is shaped in early education settings.

Would she be the mother of this girl that is sitting at the table? (The Netherlands)

There is no eye contact between adults and children. Only the correcting teacher looks at the children. They do not direct the attention towards the children. (Sweden)

Even though the educators categorised the people in the image in a similar way, there were differences in how they connected these categories to their own context. The Dutch educators said that they never work with such young children, which reflects their educational system, wherein childcare services and education are provided separately. The Nordic educators did not address children's ages as unfamiliar. Another example of differences concerns the person sitting on a bench in the image. The educators most often interpreted that person as a mother. However, there were differences even within one country in how educators viewed parents' roles in educational settings. For instance, one Finnish educator expressed that parents must be invited to participate in the daily lives of educational settings, whereas another educator stated that the parents' role is neither to observe nor to participate in activities. 
Throughout the group discussions, the educators characterised the child group in the image as diverse. When thinking and talking with the image, educators in all countries drew attention to ethnic and cultural differences as well as children's individual (special) needs as differentiating aspects within the group. Like the Finnish and Icelandic educators cited below, the educators connected certain bodily features and material cues, such as skin colour, clothes, black glasses and a wheelchair, to children's backgrounds and needs. Moreover, the educators tended to look at the group more from the perspective of differences than similarities.

There are clearly children with different cultural backgrounds. And then, here one can see a boy with a white stick. He has problems with sight. And then there's a child sitting on a different chair. He might have some problems with moving? This looks like a diverse group and one can see a principle of inclusion as all are in the same group. (Finland)

I notice that there's diversity in students and we also have that. Not just cultural differences but also learning differences and developmental differences, you can see who is in need of different attentions. (Iceland)

The educators' interpretations showed implicit assumptions about what was seen as normal and deviant in early education settings. Belonging to ethnic and cultural minorities was seen as an aspect differentiating a child from others. Similarly, there seemed to be assumptions about how normal children develop, what kinds of abilities they have and which children deviate from this norm.

Sometimes you've children who have autism, who are not engaging with others or having difficulties. (The Netherlands)

Educator 1: We haven't so many children who are from other religions, like Muslims. Educator 2: We have them, you know, children who don't eat all sorts of meat. (The Netherlands)

When talking about specific social locations, such as belonging to "foreigners" or "children with individual needs", the educators not only referred to certain societal structures, but tended to attach meanings to those categories. For instance, they made assumptions about the characteristics, lifestyle and actions of children with minority backgrounds or individual needs. In the excerpts above, the Dutch educator connects the category of autism with difficulties in social relations, and the category of Muslim with specific dietary restrictions.

\section{Children's belonging: Identifications and emotional attachments}

The educators connected children's belonging to physical closeness, togetherness and joint activities with peers, and emphasized joy and happiness as prerequisites for children's belonging. They developed imagined narratives of who the people in the image were, how they experienced the situation and what kinds of emotional bonds and interactions existed between them. The educators reflected on the children's body language and facial expressions and saw a variety of emotions, such as unhappiness, loneliness, discomfort, upset, anger, excitement, happiness and satisfaction. They addressed three emotionally loaded interactions in the image that have significance for children's belonging: opposing, joint play and being alone.

In all group discussions, the educators drew attention to the interactions where children seemed to be opposed to other children or adults. These children were physically close to other people but, 
emotionally, there seemed to be something that broke down the communion. The educators interpreted that these children were raging or quarrelling. The educators referred to two details in the image. First, they addressed a child who sat on an adult's lap on the floor (Picture 1). The educators speculated about the adult's behaviour and supposed that the child might be showing rage, aggression or anger and needed comfort. In the excerpts below, the Swedish and Icelandic educators interpret holding, controlling and comforting as an adult's reactions to the child's emotions and actions.

I don't know why she's sitting there and holding this child. It might be because the child is aggressive and can run away and do something. (Sweden)

Teachers control or something. She's holding the child; I don't know if she's just trying to calm it down or not? (Iceland)

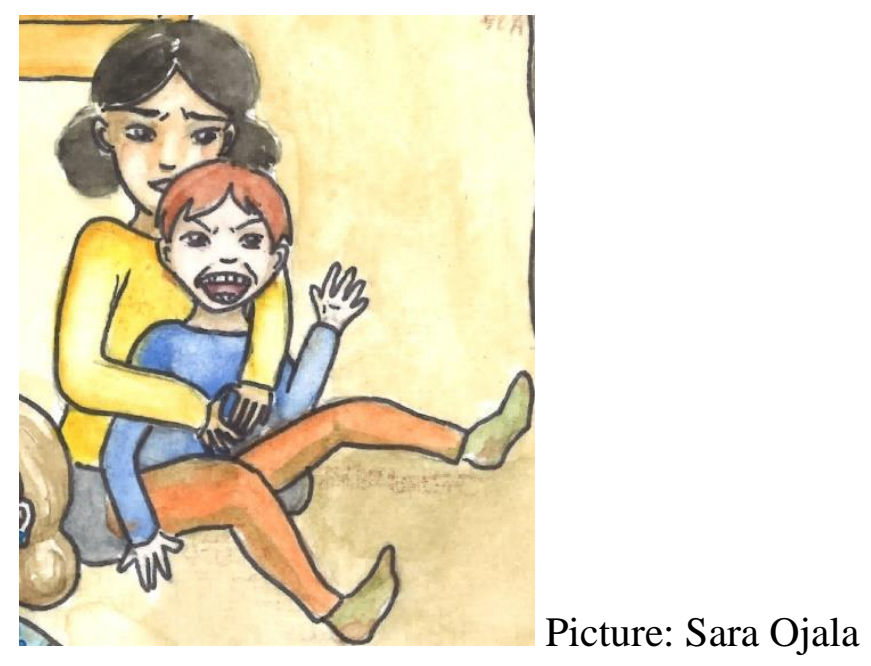

Picture 1. "A raging child"

Second, the educators noticed two children and an adult sitting by a table (Picture 2). According to the educators' interpretations, these children's interactions were coloured by quarrelling, and the educators characterised the children as feeling angry and being upset. The educators acknowledged that one of the children was crying and called her "a crying girl." Some educators interpreted that the teddy bear might be a reason for the children's quarrelling. A closer look at the educators' language showed that they employed verbal expressions that referred to children's separateness rather than to belonging. As the excerpts below illustrate, "the crying girl" and "the other one" were seen as opposing each other.

Crying child and the other one is angry, and behind one is holding another child. (The Netherlands)

Another teacher comforts the crying girl. Has she quarrelled about the teddy bear with the other girl? (Finland) 


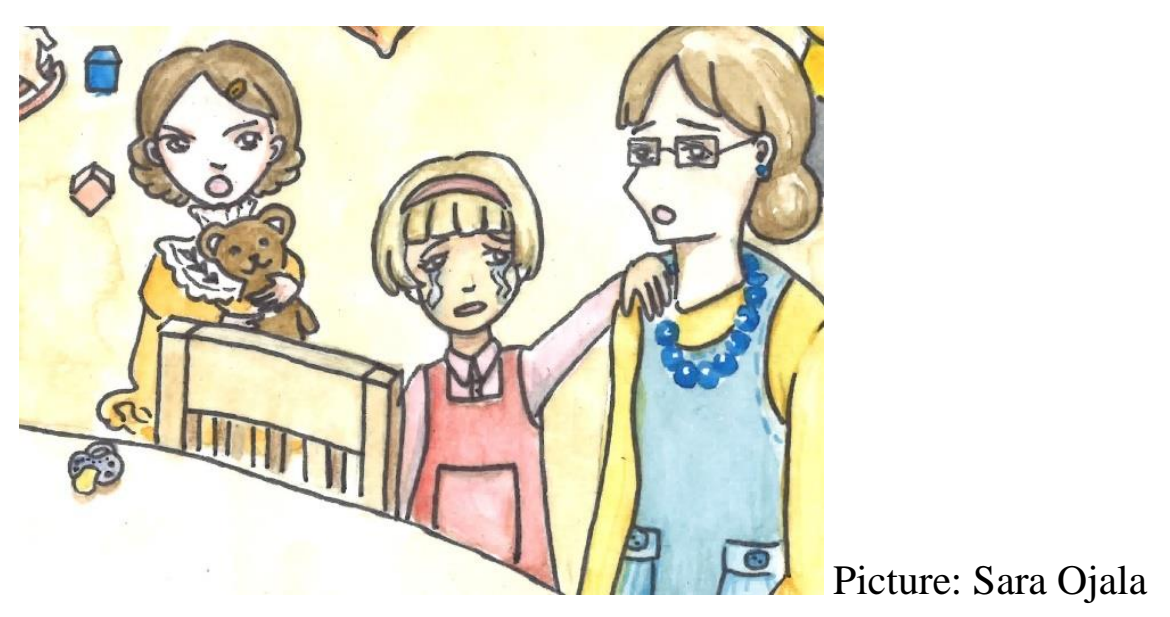

Picture 2. "Quarrelling children"

A different emotional atmosphere appeared from the educators' group discussions when they drew attention to two children who were playing with balls in the image (Picture 3 ). The educators seemed to similarly interpret that the children enjoyed the joint playing and were joyful, satisfied and happy. The educators interpreted that an adult's response to the children's jubilation was to control, discipline and silence the children. As the excerpts from Sweden and Norway show, the educators used the personal pronoun 'they' when addressing these two children, thus connecting the children in a companionship.

The children jumping on the balls look happy. They are involved in the same activity. (Sweden)

It looks like they really enjoy, and an adult standing (and says): 'Now you are making noises.' (Norway)

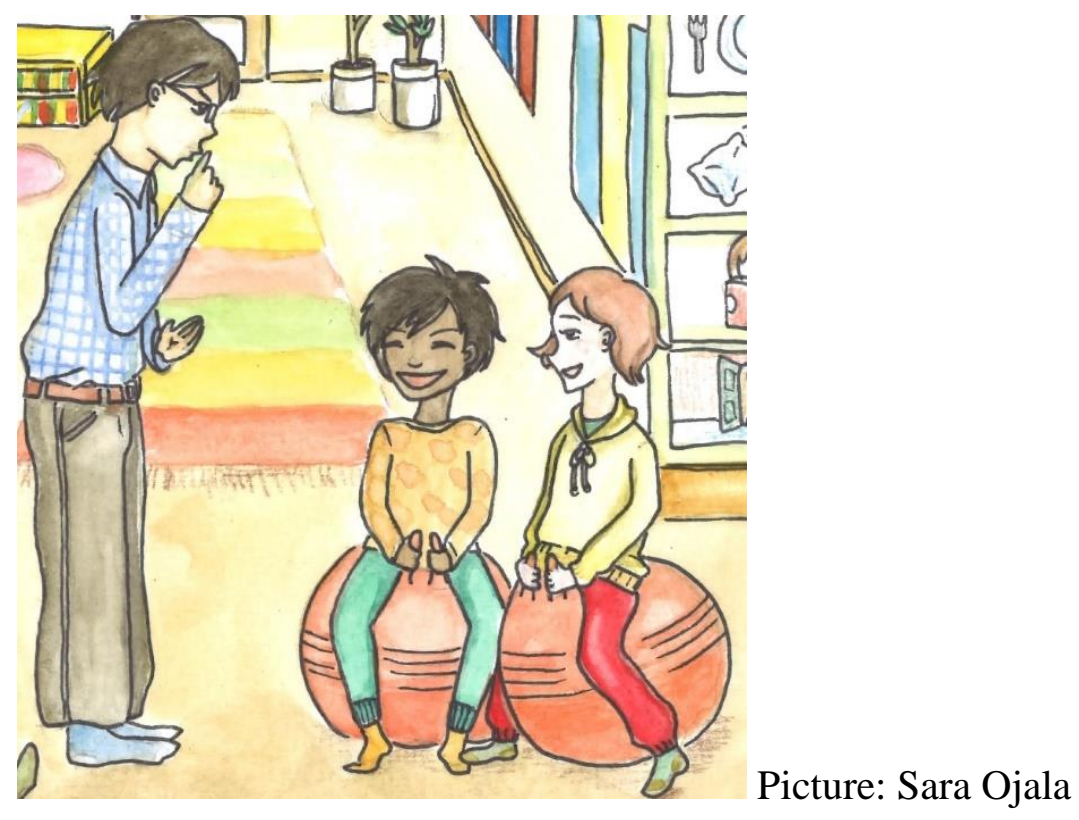

Picture 3. "The happy children" 
Being engaged in joint activities emerged as significant for children's belonging in the educators' interpretations. Therefore, the persons who were not engaged in joint activities received much attention. For example, the educators talked a lot about a person who was lying on the floor and reading a book (Picture 4). The educators interpreted that the person reading was a child-more specifically, a boy - thus locating the person in specific categories of age, gender and generation. Aside from categorising, the educators interpreted various emotions and experiences in the child's image. This child was characterised as being lonely, which is a significant notion with regards to belonging.

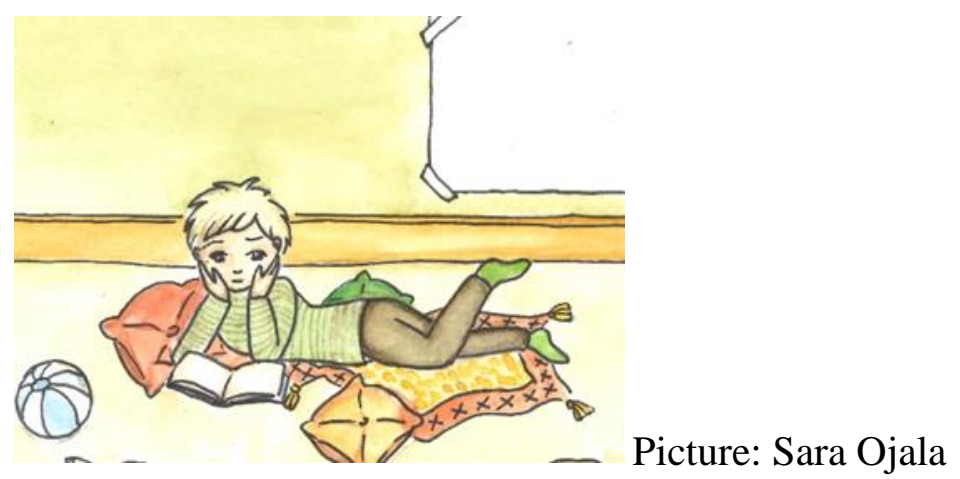

Picture 4. "The lonely boy"

However, the educators had different interpretations of how this "lonely boy" experienced the situation. The Finnish and Icelandic educators thought the child looked unhappy or disturbed, whereas the Norwegian educator interpreted the child's emotional expressions more positively.

This reading boy might be disturbed because of the noise, he looks unhappy. He might be disturbed because he tries to concentrate. (Finland)

The child in the reading area is not feeling especially well. (Iceland)

It looks like he enjoys himself. It does not look like he feels uncomfortable. (Norway)

The educators discussed whether being alone was the child's own choice or a punishment for what happened before the situation. Being alone in the highly social environment of institutional early education emerged as a tense matter. On one hand, the educators recognised that a child would need some private space for resting and having a quiet moment amidst the daily heat of being in a group. On the other hand, there seemed to be implicit expectations that children need to be involved in joint activities. From the latter viewpoint, being alone in a social situation was a potential indication of one's exclusion and a threat to one's belonging.

\section{Children's belonging - values, judgements, and tensions}

The educators' discussions around the image were value-laden; they did not address the image in a neutral way but, rather, judged, criticised and appreciated matters they saw in it. The educators emphasised issues that connect to democratic values, such as diversity, participation, equality and equity. As noted by the Swedish educator below, a diverse early education environment can provide 
children with opportunities for learning to encounter and live with different people. The Finnish educator, in turn, noted the pictures on the wall and the many languages depicted in the image. The educators viewed utilising the material environment as an appropriate means for inclusion; they noted that diverse children's belonging and feeling at home can be promoted through different material items, symbols and languages.

Since we almost only have foreign children in our preschool, the Swedish children get an insight in other languages and in other ways of playing. Children in mixed groups get more understanding of each other. (Sweden)

There seems to be a visual schedule, a simple one hanging on the wall. And welcoming with many languages. The families are considered in that way. (Finland)

We found tensions in the educators' discussions regarding how to embody democratic values and how to promote children's belonging in the daily lives of early education settings. The educators described how children's agency and their opportunities to influence their actions clashed with the adults' authority and the rules of the setting. As shown in previous sections, joint play involved the potential for promoting children's togetherness but also for causing noise that disturbs other children and especially adults. Throughout the group discussions, the educators pointed out the adults whose actions they interpreted as controlling and disciplining, thus referring to the asymmetric power relation between children and adults. A harmonious early education environment was highly appreciated by the educators. The following excerpt from Sweden illustrates how the educators criticised the image's messy atmosphere and suggested how the activities could be better organized.

We try to spread out in our preschool. Spread out the adults, so the children don't run around. You're there, and you're there. In the image, everyone is in the same space. (Sweden)

The educators discussed how children's equity was realised and how different children, as part of a diverse group, might experience the situation depicted in the image. The educators' interpretations showed that the diversity of children demands individualised support from educators, and they doubted whether the children with individual needs received enough support. For instance, in the following excerpts, the Icelandic and Norwegian educators question how "the blind boy" might experience participating in a circle time where the joint activity is to look at a book.

In the reading section, a child who needs additional support is just left there. He doesn't see the pictures, so maybe he can come closer, not leave him out, provide some support there. (Iceland)

He is not quite a participant, doesn't get the information in the same way as the others about what they are looking at. (Norway)

The excerpts from this section provide examples of the micro-political tensions shaping children's belonging in institutional educational settings, namely tensions between children's agency and the institutional conditions of early education settings; between individuals and groups of children; and between diversity and equity. On one hand, the educators viewed that gathering children with different backgrounds and needs into the same group offers a potential space for everyday democracy by enabling children to encounter differences in their daily lives. On the other hand, the educators considered that mere physical presence does not guarantee children's experiences of 
inclusion, belonging or equity. They recognised that not all illustrated children had equal opportunities for participating in and enjoying the joint activities.

\section{Discussion}

Drawing from a micro-political perspective, the starting point of this study was that educational institutions have powerful functions for supporting or restricting children's belonging (Karlsson, 2019; Kelchtermans and Vanassche, 2017). The study's aim was to advance knowledge about educators' interpretations of children's belonging in early education settings. An image was employed to gain insights into educators' interpretations of children's belonging in a research context where interpretations occur across linguistic and national borders. This study contributes to educational research and practice by advancing nuanced empirical knowledge about how educators view educational settings as sites for children's belonging. As educators play a key role in shaping children's belonging (Nutbrown and Clough, 2009; Tillett and Wong, 2018), the study's findings can be used in training early education staff and developing pedagogical work. Moreover, the study provides a concrete example of "thinking and talking with an image" as a methodology in exploring educators' cultural knowledge and values in cross-cultural research. We discuss our key findings below, along with the methodological potential and challenges of thinking and talking with an image in cross-cultural research.

\section{To make an un-reflective categorisation reflective}

This study contributes to educational research and practice by explicating educators' taken-forgranted and un-reflected categorisations, thus portraying educators' views about the social milieu within which children's belonging is shaped in educational settings. One of the most striking notions of this study was that educators in all countries drew attention to ethnic and cultural differences as well as children's individual (special) needs as differentiating aspects within the group of children. In addition, the educators categorised people according to their ages, genders, generations and positions within institutional education. Previous research has argued that categorising people is an automatic part of humans' ability to navigate the complex social world (Rosenberger and Stöckl, 2016). However, there is an increasing body of research that problematises the inevitability and normality of stable social categories. Rosenberger and Stöckl (2016), for instance, point out how immigrant background is not only a structural category but also a category of self- and otheridentification. Yuval- Davis (2006: 201) emphasises that the categories of belonging are neither natural nor neutral but, rather, a product of human creative freedom and autonomy: "Rainbows include the whole spectrum of different colours, but how many colours we distinguish depends on our specific social and linguistic milieu." Our findings challenge educators to reflect on their views about social categories and on how children's belonging is both promoted and hindered by categorisation in educational settings. By becoming conscious of the power relations implicit in the categories, educators might be able to take further steps towards practices that support all children's belonging (see Phillips, 2010). The need to support children's belonging is an urgent challenge that educators confront in increasingly diverse educational communities and in a highly mobile world (Healy and Richardson, 2017; Zabeli and Glejal, 2020).

\section{Emotionally loaded interactions and children's belonging}

The study provides insights into educators' views about emotionally loaded interactions that are significant to children's belonging in educational settings. The educators tightly connected children's emotions of joy and happiness with physical closeness, togetherness and involvement with others. This strengthens previous research that has shown how togetherness is created in joint 
activities and evolves gradually through joint play, stable friendships and emotional bonding (Hännikäinen, 2007; Johansson, 2017; Koivula and Hännikäinen, 2016). The educators also addressed opposing and quarrelling as situations in which children experience anger, rage, aggression and being upset. These emotional interactions break children's communion with others and influence their belonging, at least momentarily. It is important to note that being a constant collision course with adults or other children can become a severe threat to children's belonging. Some children tend to be typecast as trouble-makers, which affects their peer relations, status and belonging in a group of children (Puroila, 2019). Our findings also raise the question of how to relate to children's solitude, as being alone appeared as a potential threat to belonging in the educators' interpretations. There seem to be cultural expectations that children should be involved in joint activities: being socially active and extroverted is more desirable of children than being introverted and preferring solitary activities. Belonging to a group can thus be viewed as both a right and an obligation. A child has the right to be included but is also expected to include others and contribute to the public good in the educational institution (see Author, 2008). Notions of children's emotionally loaded interactions challenge educators to acknowledge their roles in responding to children's emotions, supporting emotional bonds among children and creating the overall emotional atmosphere in the educational setting as significant aspects of children's belonging. As Ree and Emilson (2019) note, educators' way of communication is meaningful for children's participation and belonging in a community.

\section{Diversity as a resource for democracy}

Moreover, our study challenges educators to critically reflect on values and practices related to diversity and belonging in education settings. Values, ideologies and power relations are, according to Yuval-Davies (2011), embedded in the politics of belonging. Democratic ideals seemed to be at the forefront for the educators, who emphasized the value of diversity. Even though the educators regarded diversity as a resource for everyday democracy in early education, there were tensions between diversity and equity in their interpretations. Diversity was highlighted as a democratic prerequisite, but the educators questioned whether it was possible for the illustrated children with special needs to experience equity and belonging in the group. This notion leads to the challenging question of equality in relation to equity; two different strategies for supporting fairness. Does promoting children's belonging require that all children are treated in similar ways, which relates to the idea of equality? Or should each child be provided with opportunities that best meet their individual needs, which relates to the idea of equity (also Terhart and von Dewitz, 2018)? Positive attitudes towards diversity can be regarded as a politically correct rhetoric for a conscious educator. On the other hand, early education institutions have a long tradition of inclusive ideology shaped in practice. However, the new social realities in Europe and around the world, characterised by increasing diversity, mobility and pluralism, are challenging for both educators and children in early education institutions (García-Sánchez and Nazimova, 2017; Urban, 2015). In these institutions, children and adults with different cultural, political and social backgrounds meet which may cause tensions between different values, ideologies and power positions (Puroila et al., 2016). A crucial point for educators is to manage to work in a respectful and ethically sensitive way with diverse children and families and simultaneously honouring their own values (Purdue et al., 2009).

\section{Researching with an image in cross-cultural research: Methodological reflections}

Thinking and talking with an image was developed as a methodological approach for this study to explore educators' interpretations across national and linguistic borders. This methodology has potential use in future research, but limitations must also be acknowledged. From the educators' perspective, the image created a common space for them to share ideas and experiences in their 
discussions. The image also provided a means for lowering or transgressing the professional borders between the educators and the researchers (also Puroila and Johansson, 2018); when talking about the image, the educators were in their own territory, which was more or less distant from the researchers' daily lives. Even though all educators had a right to look at the image from their own vantage points, it is most probable that the educators tended to adapt to the research situation and present themselves as competent professionals. Some educators might also have experienced group discussion as a limitation in terms of expressing intimate ideas and interpretations for colleagues. For us researchers, the educators' discussions with the image provided a window into their cultural knowledge and values concerning children's belonging in institutional early education. As Bleiker (2015) states, the interpretation of images contains values that have more to do with the interpreter's values than the content of the image itself. Collaboration within the international and multidisciplinary research team allowed us to approach children's belonging from various perspectives. On one hand, our different backgrounds enabled us to communicate with participants from various countries; as 'insiders', we had an opportunity to gain nuanced understandings of what the educators in each country were expressing (see McNess et al., 2015). On the other hand, the different backgrounds provided distance and 'outsiderness' (see McNess et al., 2015) and obliged us to cross borders between nations, languages and professions. Combining the insider and outsider perspectives appeared a fruitful means of deepening our understanding of children's belonging in the context of cross-cultural research.

\section{Professionalism as a shared basis for promoting children's belonging in the European context}

As this study draws on a micro-political perspective to children's belonging (Karlsson, 2019; Kelchtermans \& Vanassche, 2017), it is beyond its scope to articulate macro-level conclusions about similarities and differences among the five European countries. However, some similarities and differences in the micro-politics of educational settings can be identified. One interesting finding was that educators from different countries had much in common in their interpretations of children's belonging in early education settings. The educators in all participating countries recognised familiar features of daily life in an educational setting in the image. The discussions around the image contained professional language and references to routines that are thoroughly familiar to educators working with young children, such as gathering children into circle time or employing visual schedules. The participants recognised these familiar features in the image because they have been socialised into the professional cultures of early education. Besides recognising familiarities, the educators addressed what they felt was strange and also were critical of what they saw. The differences in the educators' interpretations did not follow national borders but there were different interpretations within one country. In general, the shared basis of the profession appeared as a more significant basis for educators' interpretations than the different societal contexts did (also AndresonLewitt, 2012; Puroila and Johansson, 2018). This does not mean that the national-level differences or their significance to children's belonging should be denied. Rather, the study suggests that there are enough common features in educators' professionalism in different European countries to collaborate in promoting children's belonging. We propose that, in the European context, dialogue across borders provides a potential means for educators and researchers to co-construct knowledge and learn from each other. Deepening understanding of the shared professional core of early education emerges as a crucial challenge for future research. A shared understanding of early education enables educators, researchers and policy-makers to promote common European values based on democracy by developing early education settings that support all children's belonging.

\section{Acknowledgements}

We would like to thank Sara Ojala for drawing the image for this study and permission to publish the image (publishing agreement dated May $21^{\text {st }} 2018$ ). 


\section{Funding}

The author(s) disclosed receipt of the following financial support for the research, authorship, and/or publication of this article: The study is part of the research project 'Politics of belonging: Promoting children's inclusion in educational settings across borders', funded by NordForsk research programme 'Education for Tomorrow' (project number 85644).

\section{References:}

Ainscow M (2020) Promoting inclusion and equity in education: lessons from international experiences. Nordic Journal of Studies in Educational Policy 6(1): 7-16.

Allan A and Tinkler P (2015) 'Seeing' into the past and 'looking' forward to the future: visual methods and gender and education research. Gender and Education 27(7): 91-811.

Anderson-Lewitt K (2012) Complicating the concept of culture. Comparative Education 48(4): $441-454$.

Bleiker R (2015) Pluralist methods for visual global politics. Millennium Journal of International Studies 43(3): 872-890.

Boden Z, Larkin M and Iyer M (2019) Picturing ourselves in the world: drawings, interpretative phenomenological analysis and the relational mapping interview. Qualitative Research in Psychology 16(2): 218-236.

Couchenour D and Chrisman JK (eds) (2016) The SAGE Encyclopedia of Contemporary Early Childhood Education. Volume 1. Thousand Oaks: SAGE.

Council of the European Union (2018) Council recommendations on promoting common values, inclusive education, and the European dimension of teaching (22 May 2018). Available at https://eur-lex.europa.eu/legal-content/EN/TXT/PDF/?uri=CELEX:32018H0607(01)\&from=EN (accessed 29 March 2021).

Emilson A (2008) Det önskvärda barnet. Fostran uttryckt $i$ vardagliga ommunikationshandlandingar mellan lärare och barn i förskolan. [The desirable child in preschool.] Doctoral thesis. Göteborg: ACTA Universitatis Gothoburgensis.

European Commission (2020) Early Childhood Education and Care. How to Recruit, Train and Motivate Well-qualified Staff? Brussels: European Commission.

Eurydice (2019) Key Data on Early Childhood Education and Care in Europe-2019 Edition. Eurydice Report. Luxembourg: Publications Office of the European Union.

García-Sánchez I and Nazimova K (2017) Language socialization and immigration in Europe. In: Duff PA and May S (eds) Language socialization. Cham: Springer, pp. 441-456.

Guo K \& Dalli C (2016). Belonging as a force of agency: an exploration of immigrant children's everyday life in early childhood settings. Global Studies of Childhood 6(3): 254-267. 
Hännikäinen M (2007. Creating togetherness and building a preschool community of learners: The role of play and games. In: Jambor T and Van Gils J (eds) Several Perspectives on Children's Play. Antwerpen and Apeldoorn: Garant, pp. 147-160.

Healy M and Richardson M (2017) Images and identity: children constructing a sense of belonging to Europe. European Educational Research Journal 16(4): 440-454.

Johansson E (2017) Toddlers' relationships: a matter of sharing worlds. In: Li L, Quinnes G and Ridgeway A (eds) Studying Babies and Toddlers: Relationships in Cultural Contexts. Singapore: Springer, pp. 13-28.

Juutinen J (2018) Inside or outside? The small stories about the politics of belonging. Acta Universitatis Ouluensis, E Scientiae Rerum Socialium, 179. Academic dissertation. Oulu: University of Oulu.

Juutinen J, Puroila A-M, and Johansson E (2018) “There is no room for you!" The politics of belonging in children's play situations. In: Johansson E, Emilson A and Puroila A-M (eds) Values Education in Early Childhood Settings: Concepts, Approaches and Practices. Cham, Switzerland: Springer, pp. 249-264.

Karlsson S (2019) 'They cry, cry, they want to go to school': the micro-politics of asylum-seeking children's articulated emotions and belonging in relation to the Swedish school. Children \& Society 33(5): 429-442.

Kelchtermans G and Vanassche E (2017) Micropolitics in the education of teachers: Power, negotiation, and professional development. In: Clandinin DJ and Husu J (eds) The SAGE Handbook of Research on Teacher Education. Volume 1. London: Sage, pp. 442-456.

Koivula M and Hännikäinen M (2016) Building children's sense of community in a day care centre through small groups in play. Early years 37(2): 126-142.

Kyrönlampi T, Uitto M and Puroila A-M (2021) Place, peers, and play: children's belonging in a preprimary setting. International Journal of Early Childhood. Online first.

https://doi.org/10.1007/s13158-021-00285-9

McNess E, Arthur L and Crossley M (2015) 'Ethnographic dazzle' and the construction of the 'Other': revisiting dimensions of insider and outsider research for international and comparative education. Compare: A Journal of Comparative and International Education 45(2): 295-316.

May V (2013) Connecting Self to Society. Belonging in a Changing World. New York, NY: Palgrave Macmillan.

Milligan L (2016) Insider-outsider-inbetweener? Researcher positioning, participative methods and cross-cultural educational research. Compare: A Journal of Comparative and International Education 46(2): 235-250.

Nagel C (2011) Belonging. In Del Casino VJ, Thomas ME, Cloke P, et al (eds) A Companion to Social Geography. West Sussex: Wiley-Blackwell, pp. 108-124. 
Nutbrown C and Clough P (2009) Citizenship and exclusion in the early years: understanding and responding to children's perspectives on 'belonging'. International Journal of Early Years Education 17(3): 191-206.

OECD (2017) Starting Strong 20177. Key OECD Indicators on Early Childhood Education and Care. Paris: OECD Publishing.

Over H (2016) The origins of belonging: social motivation in infants and young children. Philosophical Transactions B.371:20150072. http://dx.doi.org/10.1098/rstb.2015.0072

Phillips LG (2010) Social justice storytelling and young children's active citizenship. Discourse: Studies in the Cultural Politics of Education 31(3): 363-376.

Piškur B, Beurskens AJHM, Ketelaar M, Jongmans MJ, Casparie BM and Smeets RJEM (2017) Daily actions, challenges, and needs among Dutch parents while supporting the participation of their child with a physical disability at home, at school, and in the community: a qualitative diary study. BMC Pediatrics 17:12.

Purdue K, Gordon-Burns D, Gunn A, et al. (2009) Supporting inclusion in early childhood settings: some possibilities and problems for teacher education. International Journal of Inclusive Education 13(8): 805-815.

Puroila A-M (2019) Who am I? Shaping young children's identities through everyday narratives. In: Kerry-Moran KJ \& Aerila JA (eds) Story in children's lives: Contributions of the narrative mode to early childhood development, literacy, and learning. Dordrecht, the NL: Springer, pp. 55-75.

Puroila AM and Estola E (2014) Not babies anymore: Young children's narrative identities in Finnish day care centres. International Journal of Early Childhood 46(2): 187-203. DOI:10.1007/s13158-013-0096-Z

Puroila AM, Johansson E, Estola E, Emilson A, Einarsdóttir J and Broström S (2016) Interpreting values in the daily practices of preschools: A cross-cultural analysis. Special issue "Values education in Nordic preschools: Theory and practice". International Journal of Early Childhood, 48(2): 141-159. DOI:10.1007/s13158-016-0163-3

Puroila A-M and Johansson E (2018) Toward the fusion of different horizons: Methodological potentials and challenges when exploring values education in Nordic preschools. In: Johansson E, Emilson A and Puroila AM (eds) Values Education in Early Childhood Settings: Concepts, Approaches and Practices. Dordrecht, the NL: Springer, pp. 165-183.

Ree M and Emilson A (2019) Participation in communities in ECEC expressed in child-educator interactions. Early Child Development and Care 190(14): 2229-2240.

Rose G (2016) Visual Methodologies: An Introduction to Researching with Visual Materials. 4th edition. London: Sage.

Rosenberger S and Stöckl I (2016) The politics of categorization-political representatives with immigrant background between "the other" and "standing for." Politics, Groups, and Identities 6(2): 217-36. 
Skoglund RI (2020) Beyond bullying: understanding children's exploration of inclusion and exclusion processes in kindergarten. In: Hedegaard M and Ødegaard EE (eds) Children's Exploration and Cultural Formation. Cham: Springer, pp. 29-45.

Stratigos T, Bradley B and Sumsion J (2014) Infants, family day care and the politics of belonging. International Journal of Early Childhood 46(2): 171-186.

Sumsion J and Wong S (2011) Interrogating 'belonging' in belonging, being, and becoming: the early years learning framework for Australia. Contemporary Issues in Early Childhood 12(1): 2845 .

Terhart H and von Dewitz N (2018) Newly arrived migrant students in German schools: exclusive and inclusive practices. European Educational Research Journal 17(2): 290-304.

Tillett V and Wong S (2018) An investigative case study into early childhood educators' understanding about 'belonging'. European Early Childhood Education Research Journal 26(1): $37-49$.

Tracy J (2010) Qualitative quality: eight 'big-tent' criteria for excellent qualitative research. Qualitative Inquiry 16(10): 837-851.

Traue B, Blanc M and Cambre C (2019) Visibilities and visual discourses: rethinking the social with the image. Qualitative Inquiry 25(4): 327-337.

Urban M (2015) From 'closing the gap' to an ethics of affirmation. Reconceptualising the role of early childhood services in times of uncertainty. European Journal of Education 50(3): 293-306.

Wastell SJ and Degotardi S (2017) 'I belong here; I been coming a big time': an exploration of belonging that includes the voice of the children. Australasian Journal of Early Childhood 42(4): $38-46$.

Wendt M (2020) Comparing 'deep' insider knowledge: developing analytical strategies for crosscultural qualitative studies. International Journal of Social Research Methodology 23(3): 241254.

Yuval-Davis N (2006) Belonging and the politics of belonging. Patterns of Prejudice 40(3): 197214.

Yuval-Davis N (2010) Theorizing identity: beyond the 'us' and 'them' dichotomy. Patterns of Prejudice 44(3): 261-280.

Yuval-Davis N (2011) The politics of belonging. Intersectional contestations. London: Sage.

Zabeli N and Gjelaj M (2020) Preschool teachers' awareness, attitudes and challenges towards inclusive early childhood education: a qualitative study. Cogent Education 7(1): 1791560. 


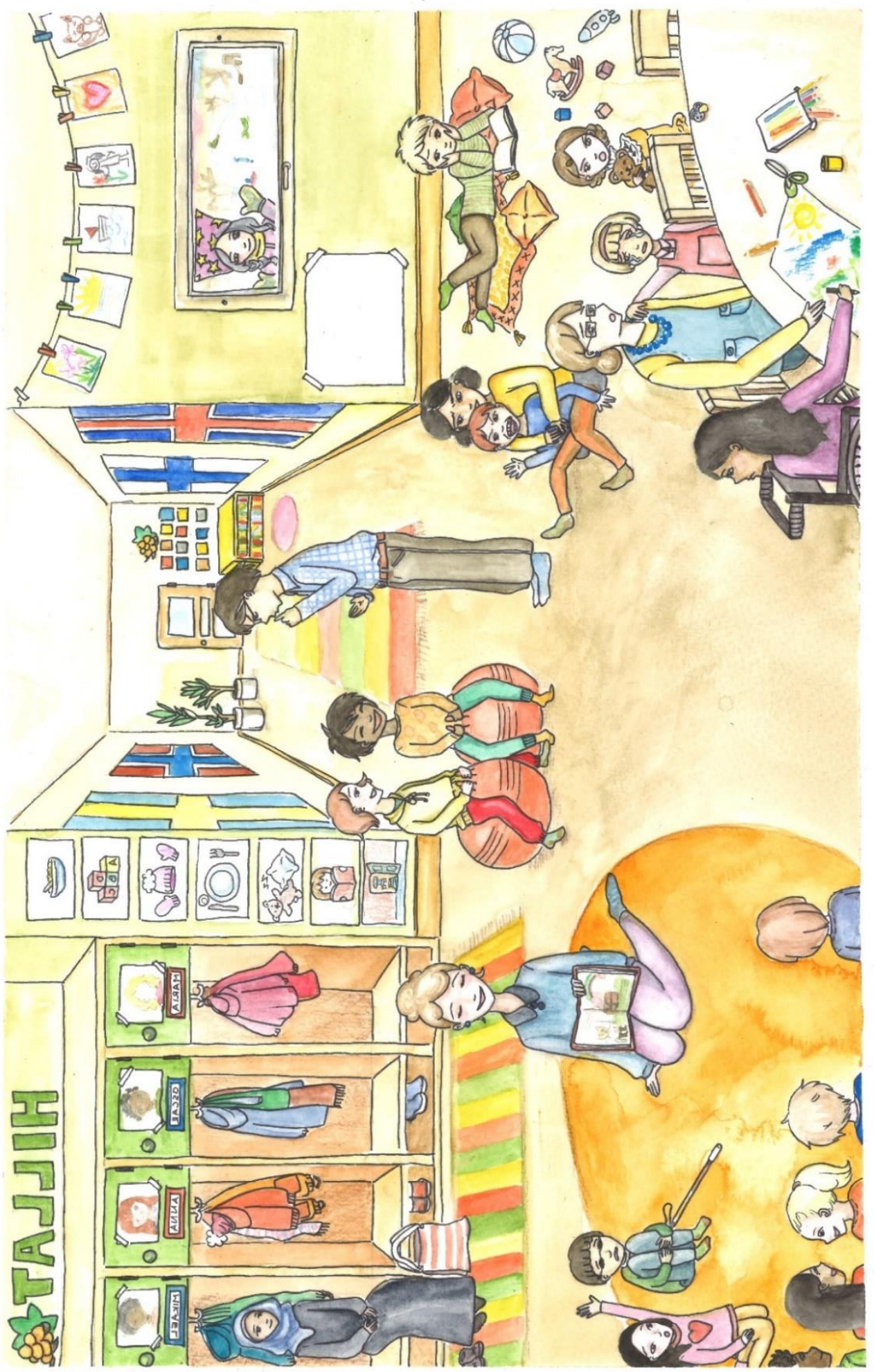

Picture: Sara Ojala 